\title{
Possible Seismicity of the Nacimiento Fault, California
}

\begin{abstract}
Earthquake history and instrumentally located epicenters suggest that this fault is active at depth.
\end{abstract}

The Nacimiento fault zone, in the Coast Ranges between $35^{\circ}$ and $36^{\circ}$ north latitude (Fig. 1), has been much studied as marking an important stratigraphic and petrologic boundary. Whether or not it is now active in the sense of tectonic displacement and earthquakes is a question of scientific interest and of possible economic importance.

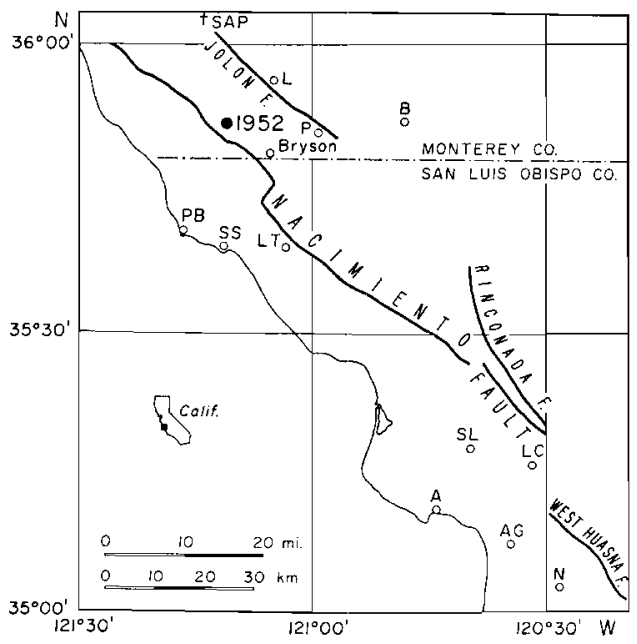

Figure 1. Index map, showing location of Nacimiento fault and other faults mentioned, epicenter of earthquake of November 21,1952 , and localities as follows: Avila (A), Arroyo Grande (AG), Bradley (B), Bryson, Las Tablas (L'T), Lockwood (L), Lopez Canyon (LC), Nipomo (N), Piedras Blancas (PB), Pleyto (P), San Antonio de Padua Mission (SAP), San Luis Obispo (SL) and San Simeon (SS).
To save repeating details, the reader is referred to a recent paper (Hall and Corbató, 1967); the authors cite earlier investigations. They note evidence of displacement on the Nacimiento fault in the Miocene, but do not discuss the possibility of later displacements. See also Oakeshott (1966), Page (1966), and Vedder and Brown (1968).

It is sometimes stated, without citing any authority, that the Nacimiento fault is now not active (Oakeshott, 1966, p. 367; Page, 1966, p. 268). Properly, this should refer to failure to find geological field evidence of Quaternary or Holocene displacement; but, apparently, it is also thought that historical and instrumental seismology gives no indication of current activity. This is an error, which it is the main purpose of the present note to correct.

The Nacimiento fault is in a region of more rainfall than much of California, and the vegetation is in places thick enough to interfere with examining the ground closely. After a local earthquake, minor features, such as offsets of a few inches, or low scarps of the same order, might not be found and could easily be obscured after a rainy season or two. An accidental circumstance which tends to obscure seismicity in the region of the Nacimiento fault is its position roughly midway betwcen the two seismographic head stations at Berkeley and Pasadena. Even the outpost stations of the two networks are still at considerable distances. One result of this is that small shocks originating between $35^{\circ}$ and $36^{\circ} \mathrm{N}$., and west of $120^{\circ} \mathrm{W}$., are incompletely recorded, and usually are omitted from lists because they cannot be located with confidence. 
Even for larger shocks, location is imprecise, and there is particular uncertainty about placing in the east-west direction. Whatever location work is done necessarily operates on the assumption that the general crustal structure, and the prevailing velocities of seismic waves, are the same in this area as clsewhere in California; this assumption can be only approximately valid at best. Morcover, if a larger shock is recorded at stations far to the east, such as Tinemaha, Hawee, and Cottonwood in the Owens Valley region, times are known to be affected by the interfering root of the Sierra Nevada; this is difficult to allow for, and adds to uncertainties of location. In general, any instrumentally located epicenter in the region which includes the Nacimiento fault may be in error by 5 or even 10 miles. The historical record, before the introduction of modern seismographs in California, is particularly unsatisfactory in this region, because of its generally sparse population; although San Simeon is an old port, and Mission San Antonio de Padua was founded in 1771.

For the early years, practically all the existing information is given or summarized in the large catalogue by Holden (1897). The following entries call for comment here:

1852, October 26 or November 26. (The same information appears under both dates, on different cited authority.) Eleven shocks felt at San Simeon, Los Angeles, and San Gabriel.

1852, November 27-30. Continuation of the previous. "The shocks opened fissures at least thirty miles long in Lockwood Valley." There is a small community, Lockwood, in southern Monterey County, about ten miles from the Nacimiento fault, and fairly near the Jolon fault. However, it usually has been supposed that this report, if valid, refers to Lockwood Valley in northeastern Ventura County, on the line of the Big Pine fault (Hill and Dibblee, 1953). This might well have been the epicentral area for the shocks felt at San Simeon, Los Angeles, and San Gabriel.

1853, February 1. Violent shocks at San Simeon. "Houses were injured."

Later investigations than Holden's have turned up some other events of interest.

Reference may be made to Wood and Heck (1951), revised by Eppley (1961) with a particular note of the event of April 11, 1885; noticed in Holden's catalogue as felt over a wide area without being strong anywhere. The late Maxwell W. Allen found record that it was very strong at Las Tablas, about 30 miles northwest of San Luis Obispo, where chimneys were thrown down. Wood and Heck include a speculative attribution of this earthquake to the San Andreas fault, but this does not seem very convincing. They also list:

1916, December 1. Strong at Avila; refinery smokestack collapsed.

1917, July 9. Lopez Canyon, San Luis Obispo County. Chimneys cracked and rocks rolled down hillsides. The locality is about $35^{\circ} 15^{\prime} \mathrm{N}$., $120^{\circ} 30^{\prime} \mathrm{W}$, near the southeastern course of the Nacimiento fault.

A few instrumentally located epicenters in the area are shown on maps accompanying a paper by Wood (1947). A few also appear on a map published by the California Department of Water Resources (Anonymous, 1964); this map shows the Nacimiento and other faults. The most important epicenter is accidentally misplaced on this map (see remarks below).

A number of shocks have been reported as felt strongly or causing slight damage at Nipomo and Arroyo Grande. These places are rather far from the Nacimiento fault, and near enough to the West Huasna fault for activity to be attributed to it.

Because of the uncertainties involved, it would be unremunerative to list further small shocks reported slightly felt, or instrumentally located, in the vicinity of the Nacimiento fault. In view of shocks of earlier date reported at San Simeon, it is well to note that there is almost surely an active fault near the coast in that vicinity. An earthquake of magnitude 4.6 on December 30, 1948, demonstrates this. Instrumental location made at the Berkeley station is $35^{\circ} 41^{\prime}$ N., $121^{\circ} 24^{\prime}$ W. At San Simeon the shaking was strong enough to knock canned goods off store shelves; intensity was nearly as high at Piedras Blancas Point lighthouse.

Probably the most significant event for this entire discussion was the earthquake of $\mathrm{No}^{-}$ vember 21,1952 . This had a magnitude near 6 ; it was felt from San Francisco to Los Angeles, and inland as far as Mojave.

The epicenter determined at Pasadena from the instrumental recordings at all available stations was $35^{\circ} 50^{\prime} \mathrm{N} ., 121^{\circ} 10^{\prime} \mathrm{W}$., which is almost directly on the line of the Nacimiento fault (Murphy and Cloud, 1954; Richter, $1955,1958)$. On the map accompanying Bulletin 116-2 (Anonymous, 1964), this has been mislocated, appearing about 10 miles too far south.

This has been called the Bryson earthquake, 
from a small town near the instrumental epicenter where there was damage to chimneys, broken dishes, and so forth. At the Pleyto school, about 10 miles northeast of Bryson, there was much damage to contents, but apparently not to the structure. Numerous small aftershocks were felt there. Chimneys were wisted and fell in the vicinity of Bradley, still further northeast; this locality is on rather unconsolidated ground in the valley of the Salinas River.

These events, in the writer's opinion, constitute proof of current seismic activity in the region traversed by the Nacimiento fault, with at least a probability that some of it originates on the Nacimiento fault zone. Even an earth quake of magnitude 6 , originating at the probable depth of 5 to 10 miles, would not uccssarily produce identifiable surface traces, so that there is no conllict with the negative results of field surveys. Most of these suggest a very complicated surface expression of faulting; a considerable displacement, contintous or discontinuous at depth, might brak its way to the surface in a dispersed and diminished form.

Activity of the Nacimiento fault, or of some closely associated fault, could only be established convincingly by registrations at a closely spaced network of seismological stations. Given the local conditions involving sparse population and poor communications, this would be a difficult project.

Dr. G. P. Oakeshott has kindly communicated a memorandum by Mr. Earl W. Hart, lrom which the following is quoted:

Based on my detaled feld mapping of the Nacimiento fault zonc and the brancling Rinconada faut zonc, I feel certain that surface displace. ments occurted at least as recently as the Pleistocene and possibly during Recent [Holocene] time. Structural deformation and possible truncation of the Paso Robles Formation (Pliocene and/or lower Plcistocene) ccrtainly indicates substantial postPliocene tectonism, In addition, topographic fatures (such as sag ponds, apparent drainage oflset in a right lateral sense, and probable fault searps in older alluvium) indicate late Quaternary movements along the Rinconada fault zone. Some dratn. age features along the Nacimiento fault zone in the San Luis Obispo quadrangle also suggest youhful strike slip (right lateral) movement.

Mr. Hart also refers to his published remarks on p. 258-259, following the paper by Vedder and Brown (1968).

Because of the lack of data referred to near the bcginning of this notice, it has often been supposed that the entire area is nonseismic and not subject to heavy shaking. If this error should lead to large installations with insulficient engineering provision against earthquakes, the consequences might be serious.

\section{References Cited}

Anonymous (1964), Crustal strain and fault movement investigation: California Dept. Water Resources Bull. 116-2, 96 p., 3 maps.

Eppley, R. A. (1961), Earthquake history of the United States, Part II, Stronger earthquakes of California and western Nevada: U.S. Coast and Geod. Survey [Pub.] 41-1, revised, 55 p.

Hall, Clarence A., Jr., and Corbató, Charles E., 1967, Stratigraphy and structure of Mesozoic and Cenozoic rocks, Nipomo Quadrangle, southern Coast Ranges, California: Geol. Soc. America Bull., v. 78, p. 559-582.

Hill, M. L., and Dibblee, T. W., Jr.. 1953, San Andreas, Garlock, and Big Pine faults, California: Gcol. Soc. America Bull., v. 64, p. 443-458.

Holden, E. S., 1897, Catalog of earthquakes on the Pacific coast, 1769 to 1897: Smithsonian Misc. Colln., no. $1087,253 \mathrm{p}$.

Murphy, L. M., and Cloud, W. K., 1954, United States earthqquakes, 1952: U.S. Coast and Geod. Survey serial $773,112 \mathrm{p}$.

Oakeshott, G. B., 1966, San Andreas fault in the California Coast Ranges province, p. 357-383, in Bailey, E. H., Editor, Gcology of northern California: California Div. Mines and Geology Bull. 190, 507 p.

Page, B. M., 1966, Geology of the Const Ranges of California, p. 255-276, in Bailey, E. H., Edator, Geology of northern California: California Div. Mines and Geology Bull, 190, 507 p.

Richter, C. F., 1955, loreshocks and aftershocks, p. 177-197, in G. B. Oakeshott, Editor, Earthquakes in Kern County, California, during 1952: California Div. Mines Bull. 171, $277 \mathrm{p}$.

- 1958, Elementary Seismology: San Francisco, W. H. Frceman and Co., 768 p. 
Vedder, J. G., and Brown, R. D., Jr., 1968, Structural and stratigraphic relations along the Nacimiento fault in the southern Santa Lucia Range and San Rafael Mountains, California, p., 242-258 in Dickinson, W. R., and Grantz, A., Editors, Proceedings of conference on geologic problems of San Andreas fault system: Stanford Univ. Pubs., Geol. Sci., v, xi, 377 p.

Wood, H. O., 1947, Earthquakes in southern California with geologic relations, Part 2: Seismol. Soc. America Bull., v. 37, p. 217-258, 4 maps.

Wood, H. O., and Heck, N. H., 1951, Earthquake history of the United States, Part II, Stronger earthquakes of California and western Nevada: U.S. Coast and Geod. Survey, serial 609, revised, 35 p.

Manuscript Rhcerved by The Soctety December 5, 1968

Contributron No. 1597, Division of Geological Sciences 